\title{
Cultural Production of Gender in the Mythical Plays of Karnad
}

\author{
Dr. Abhishek Kosta \\ Asst. Prof. (English) Govt. Arts College, Panagar (Jabalpur, M.P.)
}

\begin{abstract}
Girish Karnad (b.1938 -) explores human psyche and its social environment in his mythical plays-Yayati (1961), Hayavadana (1964) Naga-Mandala (1988), and The Fire and the Rain (1998) in a new way. His approach to these myths, borrowed mainly from the great Indian epic The Mahabharata and the Kathasaritasagara is "modern"l because he is mainly occupied investigating the masculine and the feminine concern as to their identity and behaviour. These plays question the patriarchal ideology of Indian society. The cultural construct generated by the patriarchal system is predominantly reflected in all the plays taken under consideration.
\end{abstract}

Key words: Patriarchal, hegemony, subjugate, antiquity, cultural construct, gender

By reinterpreting these ancient myths, Karnad's gender perspective is very much seen in keeping with the current cultural shift in gender studies. In his first play Yayati Karnad reinterprets an ancient myth of King Yayati and Devayani. The source of this myth is "Adi-Parva" of The Mahabharata. The symbolic theme of Yayati's attachment to life's pleasures and also his final renunciation is retained but his originality lies in the successful treatment of the motives of Yayati's ultimate choice. His play, Hayavadana which is highly enigmatic, Karnad had borrowed its plot from the Kathasaritasagara, an ancient collection of stories in Sanskrit literature. He is equally indebted to Thomas Mann's (1940) retelling of the story in The Transposed Heads.

In his next play Naga-Mandala, Karnad has deftly woven two Kannada folk tales. They have an existence of their own; independent of the teller and yet live only when they are passed on from one story teller to another. This oral tale is ingeniously connected to the story of Rani in the main story of play. In The Fire and the Rain Karnad has once again turned to the mythical world of Mahabharata. He has interpreted the myth of Yavakri form chapter 135-39 of 'Vana Parva' of The Mahabharata. Through this tale Karnad once again gives force to the basic human passions. All these plays reveal artistically the deep root of female subversion and male superiority which deprive women from the basic human rights

In his first play Yayati, the king Yayati meets beautiful Devyani, the only beautiful daughter of Shukracharya. He had seen her for the first time in dry well. She had been pushed into it by her friend Sharmistha, the princess of "Asura" kingdom and daughter of Vishvaparva. Yayati helped her out of the well she was drawn to Yayati and immediately asked hem to marry her, with a plea that he had lifted a maiden by her right hand, because she had gauged that Yayati, the emperor would be a worthy husband for her. Despite the caste infringements and social taboos, the marriage between Yayati and Devyani was solemnized. Sharmistha, who pushed Devyani, into the well, had to accompany Devyani after marriage for her indecent deed against Devyani.

According to Indian religious belief marriage of young adolescent girl is indispensable and being a patriarchal society she is obliged to leave her parental home and be with her husband family. Thus Devyani, like a commodity and currency has passed from one family to another. Because Devyani's father, Shukracharaya who loved his daughter could not reject her proposal due to the social construct a women cannot stay for long in her father's family when she comes of age. Before her marriage she is nursed by her father and mother and later after marriage she no longer remains a property of her parents. She has to adapt according to the norms of her husband's family. Hence due to this social construct Devyani's life after marriage is controlled by Yayati. Interpreting this myth in the light of gender theory, Luce Irigaray notices, "exchange upon which patriarchal societies are based take place exclusively among men." Yayati marries Devayani because Shukracharya possessed the power of 'Sanjeevani' i.e. nectar. Yayati's aspiration to rule over the kingdom forever makes him strike this bargain.

Sharmistha did not refrain from telling Devayani that Yayati married her not because of her beauty or deeds but because of her father's magical power of 'Sanjeevani' the power of immortality. Karnad through Sharmistha endeavours to prove that women with education and understanding do not succumb to patriarchal rules. Thus Sharmistha in this regard is a free woman who is little affected by the oppressive dictates of patriarchy. She possesses strength of mind and thus cannot bear any insult or dishonour from male sex which tries to relegate her to a position of gentle domestic creature. She does not give way to stimulate or excite tenderness and gratify the arrogant pride of man. 
Karnad by introducing the character of Chitralekha, endeavours to expose the root cause of women's oppression. For his selfish reasons, Yayati had robbed Puru of his youth and consequently robbed Chitralekha of the conjugal bliss which was her natural right. Karnad has endeavoured to paint the character of Chitralekha not as a timid or meek person who accepts masculine authority but like an enlightened woman who has ability to revolt against masculine authority. She does not passively submit to the male hegemonic behaviour of her father-in-law who tried to mould her according to his own will. The playwright has molded her character as a modern woman who does not remain silent and accept male hegemony, because she has proper education which enables her to fight against it. Her mind is reinforced by her sound education which she has received in her childhood. Because she has also learnt marshal arts like a man, Chitralekha, in the words of Wollstonecraft, "has sharpened her senses, formed the temper [Character] regulated her passion and set her understanding to work before the body arrives at maturity." 3 Karnad through the voice of Chitralekha projects the message that properly educated women should never be treated as weak, timid, meek and submissive creature. The chauvinist attitude of Yayati towards Chitralekha, Devyani and Sharmistha and Puru has surfaced only due to his male hegemonic element which is deeply rooted in him. Chitralekha does not accept his (Yayati's) social construct of gender and therefore does not withstand the suppression and supremacy of the king, when he endeavours to exercise his authority after bringing her in his palace. She reminds him that after getting married to Puru, she too has an equal right over Antahpur, the palace of queens. She flatly refuses Yayati by telling him that he has no right to imprison her in her own sex.

Gender relations are constantly changing as society progresses and Chitralekha's character in Karnad's play reflects that she is not a woman of the past who is puppet in the hands of male authority. She takes her own decisions. When she comes to know that her husband Puru had traded his youth with his father, she instantly decides to part with him. She does not wait for any authoritative male decisions for her own family. Moreover, she boldly tells her father-in-law that she had married the 'youth' of Puru and since after the exchange of his youth, this quality is no longer present in him then why should she accept him as her husband and continue to live with him (Puru). She went to extent of saying that all those qualities of youth he (Yayati) has squeezed from him then he himself should accept her as and be her man. Chitralekha feels that she has committed sin by asking her husband Puru to go away when she looked at him as 'old Puru' in the bright light of the flames. This idea of sin is again asocial construct of culturalism which the married woman stop thinking of their own interest and welfare and entertain a feeling of guilty when unable to fulfil the just or unjust demands of their men. Chitralekha overcomes this feeling of guilt soon because of self-realization and power of independent thought. Thus Chitralekha's voice is the voice of a liberated woman who fights for her rights and is ready to break the chain of male sovereignty which still continues in patriarchal society.

Inspite of the changing culture and progress of society women are less valued and dare not raise their hands or voice their feeling when it comes to the matter of choice for her own life partner. They have to suffer because patriarchy is inextricably woven in social structure and male domination continues. Women are always the loser and men often score over her. This is the case of Padmini in Hayavadana. Though she appears modern and emancipated yet she realizes the latent force of patriarchy that always favours the male. She experiences the emotional turmoil and pangs due to her relation with her husband, Devadutta and at the same time her attraction for Kapila towards whom she drifts because of his physical charm and manly habits. But when it comes to sharing life with both men social norms intervene. Padmini the only female character and also the protagonist of the play, is depicted as the most powerful figure in this drama. She is portrayed as neither docile nor servile but self-willed intelligent and independent Savita Goel points out, "She is a symbol of emancipated woman who does not accept the part of demure wife and refuses to accept the passive feminine role"4

Padmini yearns for a man who possesses both a steel body and a clever mind, and the play thus highlights in very honest manner the physical, psychological and biological needs of the female. Devadutta, who is madly in love with her, feels that there no use of these hands and head if he is unable to have her. He desperately says to Kapila, his intimate friend that his poetry cannot live without her. Though Devadutta and Kapila are the closest friend, 'one mind and one heart' yet right at the moment when Kapila sees Padmini, he instantly realizes, "Devadatta, my friend, I confess to you. I'm feeling uneasy. You are a gentle soul. But this one is fast as lightening - and as sharp. She is not for the likes of you. What she needs is a man of steel." Soon Devadutta and Padmini get married and Kapila becomes instrument in bringing them together. Devadutta is indebted to Kapila and three lived like "Ram-Sita-Lakshamana"6

As the play proceeds their relationship becomes tangles. Kapila started drifting towards Padmini and she too is captivated by his muscular, supple body. She could not suppress her feelings and says to herself, "No women could resist him." Jealousy crops up between the two friends owing to Padmini's arrival in the life of Devadutta. The Ujjain trip results in the expected storm in their relationship. Devadutta perceives the flame of love in his wife's eye for Kapila during this visit. Unable to bear the pangs of jealousy, envious Devadutta cannot make a choice of sharing Padmini with Kapila. He takes a firm decision to kill himself in the Kali temple while Padmini and Kapila are on their way to Rudra temple. He commits suicide in the temple. On their 
return Kapila was shocked to find his friend Devadutta killed himself. Finding the chopped head in the Kali temple, Kapila whispers, "No, Devadatta, I can't live without you. I can't breathe without you. Devadatta, my brother, my father, my friend..." ${ }^{8}$ Unable to think of anything, Kapila picks up the sword that was lying there in the temple and says, "You spurned me in this world. Accept me as your brother. At least in the next. Here friend, here I come. As always, I follow in your path.", ${ }^{9}$ and he too cuts off his head before Kali. Worried Padmini on reaching Kali's temple stumbles over the truncated bodies and screams,

Oh God! What's this? Both! Both gone! And didn't even think of me before they went... Devadatta, what did I do that you left me alone in his state? Was that how much you loved me? And you, Kapila, who looked at me with dog's eye-you too? How selfish you arehow unkind! What shall I do now-where shall I go? How can I go home?... And what shall I say when I get there? What shall I say happened? And who'll believe me? They all say the two fought and died for this whore. ${ }^{10}$

Padmini laments over their death on reaching the temple decides to hack-off her head but could not do so. The Kali grants her a boon that she can revive both the friends once again by transposing the two heads. This transposition of heads results in two different men - One with Devadutta's head and Kapila's body and the other with Kapila's head and Devadutta's body. On reviving themselves, both claim to be the husband of Padmini. In this claim of real husband game Kapila is the loser, because "According to Shastras, the head is the sign of a man. ... Of all the human limbs the topmost - in position as well as in importance - is the head." Padmini succeeds in having both the intellect and flesh, "Fabulous body-fabulous brain-fabulous Devadutta." 12 Padmini who craves for the best part from each man feels happy and satisfied when her claim for new Devadutta as her husband in fulfilled. She says "My Devadatta comes like a bridegroom with the ornament of a new body..." ${ }^{\prime 3}$ Virtually,Padmini had yearned for a man who should have not only fertile and clever brain but also possessed sound and steel like body. She did not feel satisfied in the company of only one. Analyzing the predicament of Padmini form gender and cultural perspective, Suman Bala rightly observes,

The extraordinary situation helps Padmini to break out of the moral codes inflicted by society. She wants that her companion in life should be an ideal man-both in brain and brawn. She wants Devadutta's mind and Kapila's body while the society forces her to seek these qualities in one man. But since such a perfect man does not exist, she succeeds in having brain and brawn, the spirit and the flesh: 'Fabulous body—fabulous brain—fabulous Devadatta' ${ }^{14}$

Padmini is afraid to establish extramarital relationship with Kapila, though when she first saw him she got fascinated by his muscular body and felt that few women could have resisted him but to accept him as her second husband would be to break the rigid codes set-up by patriarchal society. When she realized that she dare not make Kapila her life companion after getting married to Devadatta, she seized the opportunity at Kali temple and fulfilled her desire of achieving her goal. Thus her dream to find a perfect and ideal man is fulfilled. These qualities in Padmini reflect that she is a woman of perfect education and understanding because according to Mary Wollstonecraft, "A purely perfect education is the exercise of the understanding to strengthen the body and form the heart, to enable the individual to attain such habits of virtue will render it independent." ${ }^{15}$ In this regard, Karnad's Padmini can be called a symbol of emancipated woman. Finally, Kapila and Devadutta unable to live together with Padmini kill themselves in the duel and Padmini performs sati. Padmini due to the impact of male hegemonic power prevalent in the society dare not live with two males whom she is fascinated with and without them is unable to make her life happy. The play reflects the general conception of subjugation of women as stated by Helene Cixous, "Victory always amounts to hierarchy. The hirarchization subjects the entire conceptual organization to man." ${ }^{.16}$ and Padmini stands out as a strong exponent of women's liberation through her own choice.

In another play Naga-Mandala the position of Rani can be seen as a metaphor of a young girl in the bosom of a joint family where she sees her husband in two unconnected roles-as a stranger during the day and as a lover at night. Indian woman endues almost any injustice while serving her husband for family. She obeys her husband like a dumb domestic animal. The women are the worse suffers because more often than not, it is the husband who torments and deserts his wife for another woman. Commenting on the central themes of the play Sarat Babu observes,

[The play]...not only exposes male chauvinism, the oppression of women, the great injustice done to them by men and patriarchal culture but also stealthily deflates the concept of chastity. He seems to suggest that matriarchy which according to Bachofen's theory of Mother Right is the lost paradise of mankind will come again. ${ }^{17}$

The force of patriarchy has enslaved women for ages or even from time immemorial. These cultural futters are very potent yet invisible. Karnad's powerful depiction of the agony and anguish experience by Rani stands as a paradox for a predicament of a young girl trapped in a net of patriarchy. Appanna, Rani's husband, behaves like a male chauvinist who does not care for the female feelings and forces his wife to comply with his bids. He treats her as if she were a non-human being. She does not allow her to move out form the four walls of 
her own house. She is thus imprisoned in her own house. Karnad through Rani's predicament endeavours to expose how women fall victim to male and patriarchal culture. He exposes the fact that men enjoy liberty but women are kept in a bird's cage on account of the aggressive behaviour of male. She is mercilessly kept starved of her affection and love which is indispensable for growth and sustenance of her mind. Sarat Babu comments, "Rani solitary confinement symbolizes the chastity belt of the Middle Ages: The reduction of women's talents to house work and the exclusion of women from enlightenment and enjoyment."18

Karnad through Rani's plight endeavours to project that in Indian Society a husband can be as cruel and callous as he wishes, but Indian wife cannot think of doing any harm to him. Appanna as a male chauvinist thinks he has a right to do whatever he wishes and whatever he does is always right. He is insensible to her feelings which reflect that he is subjected to patriarchal cultural and is playing his role as such. Naga, disguise as Appanna, visits at night to Rani through drainage, succeeds in his mission and like a male chauvinist is able to prove that women are foolish and ignorant. The attitude of Naga towards Rani also reflects that how men of patriarchal culture suppress the intellect of women and how their ignorance gives men the freedom of doing whatever they wish. Wollstonecraft also expresses a similar view when she says, "These [women] fellow creatures are deprived of education and are rendered weak and wretched" ${ }^{19}$ Whenever Rani endeavours to raise any questions, she is silenced by Naga, saying, "Don't ask why" ${ }^{20}$ and by Appanna as "Do as you are told, you understand" 21 This dominant attitude of her husband, Appanna and submissive nature of Rani supports the view of Radical feminists who hold that "root cause of women's oppression is patriarchal gender relation as opposed to the legal system of class conflict." ${ }^{22}$ Thus, Rani who has been brought up by her parents with great love and pampering, falls a victims in the hand of Appanna (any man) who is licentious, lewd and ludicrous. Karnad through the characters of Rani and Appanna exposes the fact how virgins fall in the net of males who exploits and suppress them to fulfil their needs.

Patriarchal hegemony is also very much apparent in Karnad's play The Fire and the Rain. A deeper analysis of the relationship between Nittilai and Arvasu reveals the fact that even in the lower class society woman has to struggle with men to establish her relationship. She has to move according to the rigid codes made by the males of the society in which men always had an upper hand. Vishakha's character in the play reveals that she too is like a true conventional Indian wife who gets moulded according to the social norms and conditions. Age old repression and suppression have deeply embedded in her subconscious mind and the sense of inferiority as a part of the collective sub consciousness of the woman folk is easily seen in her.

Raibhya's attitude in the play like that of King Yayati superimposes the male tyranny over female. Both Raibhya and his son Paravasu are depicted as male chauvinists. Karnad has successfully established Paravasu as a materialistic person who can be labeled as a heartless, uncouth, selfish, unscrupulous and worldly man of the present age. He experiments with the body of his wife Vishakha for one complete year, bypasses his father, Raibhya, to grab the honourable rank as a chief priest in the King's Court. Deeper insight into the character of Nittilai also reveals the fact that though she is a hunter girl, her words are full of grace and wisdom. She does not care for any caste, colour and creed. She follows the religion of humanity. She is a philanthropist who looks after the sick, the needy and the starved. She rises above the selfish, the mundane. Her anxiety about rain for the people in the parched land expresses her concern for humanity as a whole. In her opinion rain does not depend on the pleasure or mercy of Lord Indra. But the unselfish love of Arvasu can bring rain. Her conviction is that even the efforts made by Yavakri to gain 'Universal Knowledge' from Lord Indra directly will not bring the welfare of mankind because he craved power for selfish reasons.

The amazing fact about these plays is that the male-female characters are juxtaposed with the special purpose of highlighting women's emancipation. The heroines in these plays are able to present their case very effectively though remaining within the social conventions of the day. The male characters are not forced to accept the female rights but led to graciously accept them as the great need for familial relationships. In this way Karnad has successfully presented the case of gender issue conforming to the recent studies that pronounces-'Gender theory is a comprehensive feminism; one that includes man, woman and child'.

\section{References:}

[1]. Srinvasa Iyengar, K.R. Indian Writings in English. (New Delhi: Sterling, 1982) 735.

[2]. Luce Irigaray, "Commodities amongst Themselves" (1977) Literary Theory: An Anthology ed. Julie Rivkin and Michael Ryan, 1st pub. 1998 (Oxford: Blackwell, 2002) 574.

[3]. Mary Wollstonecraft, "Introduction", A Vindication of the Rights of Woman. By Paul Gaber, 3 March

2008<www.en.wikipedia.org/wiki/Mary_Wollstonecraft>.

[4]. Savita Goel, "Folk Theatre Strategies in Hayavadana", The Plays of Girish Karnad: Critical Perspectives ed., by Jaydipsingh

Dodiya (New Delhi: Prestige Book, 1999)204-112, 207.

[5]. Girish Karnad, Hayavadana (Chennai: Oxford UP, 2000) 19.

[6]. Karnad, Hayavadana 19.

[7]. Karnad, Hayavadana 26.

[8]. Karnad, Hayavadana 29-30

[9]. Karnad, Hayavadana 30.

[10]. Karnad, Hayavadana 31. 
[11]. Karnad, Hayavadana 36-37.

[12]. Karnad, Hayavadana 43

[13]. Karnad, Hayavadana 41

[14]. Suman Bala, “'This mad dance of incompleteness': Search for Completeness in Hayavadana”, The Plays of Girish Karnad: Critical Perspectives, ed., by Jaydipsingh Dodiya (New Delhi: Prestige Book, 1999) 190-98, 195.

[15]. Mary Wollstonecraft, "Introduction" A Vindication of the Rights of Woman By Paul Gaber. 31 Aug 2006 <www.en.wikipedia.org/wiki/Mary_Wollstonecraft>.

[16]. Helene Cixous, "Sorties" Literary Theory: An Anthology Julie Rivkin and Michael Ryan ed., Revised ed., 1st pub. 1998 (Oxford; UK: Blackwell, 2002) 579

[17]. Sarat Babu, "The Concept of Chastity and Naga Mandala", The Plays of Girish Karnad: Critical Perspectives, ed., by Jaydipsingh Dodiya (New Delhi: Prestige Book, 1999) 237-48, 238.

[18]. Sarat 239 .

[19]. Mary Wollstonecraft, "Introduction", A Vindication of the Rights of Woman. By Paul Gaber, 3rd March 2008 <www.en.wikipedia.org/wiki/Mary_Wollstonecraft>.

[20]. Girish Karnad, Three Plays: Naga-Mandala; Hayavadana; Tughlaq 1st pub. 1994 (New Delhi: Oxford University Press, 2002) 43.

[21]. Karnad, Three Plays 28.

[22]. Imelda Whelehan, Modern Feminist Thought: From second Wave to Post-Feminism (New York: New York UP, 1995) 28. 